\title{
The Gains and the Pains of Integrated Payroll and Personnel Information Systems (IPPIS) Policy Implementation in Nigeria
}

\author{
Olowu Olagunju Folorunso', Adeyemi Olufemi Simeon² \\ ${ }^{1}$ Department of Political Science and International Relations, University of Abuja, Abuja, Nigeria \\ ${ }^{2}$ Department of Business Administration, Intercontinental University, Schaumburg, Illinois, USA \\ Email: olagunju.olowu@uniabuja.edu.ng,Adeyemisimeon1971@gmail.com
}

How to cite this paper: Folorunso, O. O., \& Simeon, A. O. (2021). The Gains and the Pains of Integrated Payroll and Personnel Information Systems (IPPIS) Policy Implementation in Nigeria. Journal of Human Resource and Sustainability Studies, 9, 551-569.

https://doi.org/10.4236/jhrss.2021.94035

Received: August 25, 2021

Accepted: December 11, 2021

Published: December 14, 2021

Copyright $\odot 2021$ by author(s) and Scientific Research Publishing Inc. This work is licensed under the Creative Commons Attribution International License (CC BY 4.0).

http://creativecommons.org/licenses/by/4.0/

\begin{abstract}
The study examined the gains and pains of Integrated Payroll and Personnel Information System (IPPIS) Policy implementation in Nigeria. The paper was qualitative descriptive one. The study found that IPPIS has been able to mitigate problems associated with salary payment of public servants but the feat came with some pains or burdens to both public servants and IPPIS implementers. The study recommends among others that: the IPPIS should decentralize its activity, get more autonomy to operate effectively and the need for the remodification and redesigning of the software to accommodate more organizational flexibility and peculiarity.
\end{abstract}

\section{Keywords}

IPPIS, Public Policy, Policy, Implementation, Nigeria

\section{Introduction}

In Nigeria, the issue of public service salary has been at the forefront right from early stage of Nigerian nationhood. While the mode of payment evolved from time to time, the minimum wage was a subject of unending debates between labour and government in Nigeria. Earlier stage, payments are done through cash payment, cheque, bank overdraft and latter bank transfer after the bank's reconsolidation. Unlike America and Europe, period of salary payment in Nigeria is usually a month and this is a popular practice in the public service. Being a federal state, the issue of minimum wages and method of payment implementation had generated a lot of crises between states and the federal government. Most times, the states refused to pay the new implemented minimum wage on the 
excuse of not being economically buoyant to do so thus leaving state employees pauperized.

Since the return of civil rule 1999, lots of reforms have been carried out in the Nigerian public service which has revolutionized salary administration. The recent salary administration reform came with the introduction of electronic payment system which was designed to replace the cumbersome obsolete process that has characterized salary payment. It was on this basis that the federal government introduced the Integrated Payroll and Personnel Information System (IPPIS) to efficiently and effectively meet the needs of public servants in Nigeria and to block leakages and corruption in public service through payroll system, although, the introduction and implementation of IPPIS were faced with slight resistance from few segments of the federal government Ministry, Department and Agency.

The introduction of IPPIS in 2006 and the subsequent implementation in 2007 with core objectives: to pay federal government employee on time and accurately, to have a centralized payroll system that meets the needs of federal government employee and helps government to plan and manage payroll budget by ensuring proper control of personnel cost, have been riddled with lots of inconsistencies.

The need to develop and inspire the human resources area in an era of dwindling oil price in the international market became absolutely important as the country cannot cope with the attendant effects of low morale of federal employees as a result of irregular salary payment which is capable of demotivating workers from achieving optimal performance. In the paper, conceptual clarifications, theoretical framework of the paper, objectives of IPPIS, achievements of IPPIS, reasons for resistance of MDAs, IPPIS enrollees, gain and pains of IPPIS are discussed.

\section{Focus of the Study}

The following questions guide the study: What are the gains and achievements of IPPIS Policy implementation in Nigeria and What are the attendant challenges and pains associated with the implementation of IPPIS policy in Nigeria? While objective of the study includes to examine the gains and achievements of IPPIS Policy implementation in Nigeria and to identify the attendant challenges and pains associated with the implementation of IPPIS policy in Nigeria. Based on the study's questions and objectives, the below assumptions are set: a) the implementation of IPPIS policy in Nigeria has resulted into lots of achievement and gains to the public servants and the nation at large; $b$ ) the implementation of IPPIS policy in Nigeria has created challenges which affect public servants and government adversely.

\section{Conceptual Clarifications}

The study conceptualizes concepts that are relevant to the study. 


\section{Integrated Payroll and Personnel Information System (IPPIS)}

Enakirerhi and Temile (2017: p. 4) see IPPIS as an IT-enabled facility being put in place to establish a reliable and comprehensive database for the public service, facilitate manpower planning, eliminate record and payroll fraud, facilitate easy storage, update and retrieval of personnel records for administrative and pension processes and staff remuneration payment with minimal wastages and leakages. According to them, since the inception of the project, IPPIS has saved the Federal Government of Nigeria billions of Naira by eliminating thousands of ghost workers via personnel verification exercise and salary payment process.

While Enakirerhi and Temile conceptualized IPPIS from IT-enabled facility which has assisted the government in saving billions of Farajimakin and Anichebe (2019: p. 19) view IPPIS as intervention scheme and reform when they observed that, Integrated Personnel and Payroll Information System (IPPIS): is a world Bank-Assisted project under the Economic Reform and Government Project (ERGP) which was aimed at establishing a reliable and comprehensive database for the public service, facilitate manpower planning, assist in providing information for decision making, eliminate double dipping and credentials falsification, facilitate easy storage, update and retrieval of personnel record for administrative and pension process, and to facilitate staff remuneration payment. According to them, IPPIS programme enable the MDAs to fish out the ghost workers for the attainment of public probity in governance (Farajimakin \& Anichebe, 2019).

According to the Office of Accountant General of the Federal (2008), IPPIS is a child of the Federal Government Reform Programme which was conceptualized at the Bureau of Public Service Reform (BPSR) for the purpose of centralized payment of all civil servants in the employment of the Federal Government. The IPPIS project started in April 2007 with the enrolment of the seven pilot Ministries, Departments and Agencies (MDAs). It was financed through a World Bank facility of about USD 4.9 million. It was finally transferred to the Office of the Accountant General of the Federation (OAGF) in 2008. In other words, the IPPIS was introduced to serve the purpose of centralized payment of all civil servants in the employment of the Federal Government which after 13 years of introduction has not registered some agencies and departments.

The Federal Government in October 2006, conceived the Integrated Personnel and Payroll Information System (IPPIS) to provide a reliable and comprehensive database for the public service to address ghost worker also to facilitate human resource planning, eliminate manual record and payroll fraud also to facilitate easy storage, update and retrieve personnel records for administrative and pension processes, and facilitate convenient staff salary administration payment with minimal waste and leakage (Public Service Institute of Nigeria, 2011). This implies that IPPIS was conceived with a broad base objective which has not been fully achieved. 
Department of IPPIS while describing mode of its operations asserts that, the Integrated Payroll Personnel and Information System (IPPIS) is a department within the office of the Accountant-General of the federation which is responsible for payment of salaries and wages directly to government employee's bank account with appropriate deductions and remittances of $3^{\text {rd }}$ party payments such as: Federal Inland Revenue Service, State Boards of Internal Revenue, National Health Insurance Scheme, Pension Fund Administrative, Cooperative Societies, National Housing Fund, Bank Loans and Associations Dues (Office of Accountant General of the Federation, IPPIS Department Publication, 2012).

According to Effiong, et al., (2017: p. 26), IPPIS was conceived to reduce or eliminate corruption and data storage in the payroll system. According to them, in a bid to reduce corruption, the Nigerian government in October 2006, conceived the Integrated Payroll and Personnel Information System (IPPIS) to provide a reliable and efficient database for the public service to eliminate record and payroll frauds, facilitate easy storage, facilitate manpower planning, update and retrieve personnel records for administrative and pension processes and facilitate convenient staff remuneration payment with minimal wastes and leakages.

IPPIS in other words can be seen as a paradigm shift from analogue process to IT-driven digital way of pay rolling public servants. It is a multi-tasking software designed to ease human resources challenges in the federal civil service.

\section{Public Policy}

Broadly speaking public policy can be seen as statement of intentions. When seen from this perspective, public policy is regarded as an embodiment of official pronouncements on what governments would want to do or to be done on behalf of the citizenry. It consists of series of guidelines for actions to be taken in order to improve the welfare of the citizenry prepared by government or its designated agent (Dlakwa, 2008). Supporting this direction, Ikelegbe (2006) conceptualizes it as the integrated course and programmes of action that government has set and the framework or guide it has designed to direct actions and practices in certain problem area. While Anderson (1984) to align with this assertion when he conceived public policy as a purposive course of action followed by a political actor or set of actors in dealing with a problem or a matter of common concern.

Cochran (2015) believes that policy comprises political decisions for implementing programs to achieve societal goals. Public policy comprises a plan of action or programme and a statement of objectives, in other words, a map and a destination. Amdii (2010) supported this stand when he observed that public policy can be seen as a paradigm or framework which guide government decisions, provide direction in an effort to bring about development and growth.

In his own contribution, it is the proposed course of action which government intends to implement in respect of a given problem or situation confronting it. Public policy is a process of decision making or choice. This informed the posi- 
tion of Amdii (2010: p. 11) when he also observed that Public policy can be seen as choice making among available alternatives, taking into consideration the cost benefit analysis. Towing the same line of thinking, Dye (1995) considers it as anything that government chooses to do or not to do.

Nevertheless, no matter who the initiator of a public policy is, his initiatives would have to be acted upon by the government before such actions could appropriately be labeled as public policy (Dlakwa, 2008). Policies are commonly described as action plans, positions, and/or guidelines which influence decisions based on a set of processes, preferences and choices. Policies (decisions made) usually aim to implement a programme of reform or change, but retaining the status quo is also a policy (Howlett \& Ramesh, 2003).

Policies do not operate in isolation; some tertiary institutions explicitly establish requirements to ensure alignment between all institutional-specific texts (Freeman, 2013) for example Constitutions, Government Acts, among other laws. Policies can be adopted by individuals, groups/parties, privatize enterprises, but most often by the government; those adopted by the government are public policies. Public policy can be seen as decisions and choice making process of government which is authoritatively binding to solve societal problem. It is not just political pronouncement but it is also legally backed plans and programmes of government.

\section{IPPIS Policy Implementations in Nigeria}

Integrated Payroll and Personnel Information System (IPPIS) is a payroll policy that was introduced in 2006 in Nigeria. Farajimakin and Anichebe (2017) attested to the fact that IPPIS is a policy in implementation stage in their works Effect of Integrated Personal Payroll Information System on Employee Welfare: Evidence from Federal Ministries in Nigeria. Also, the study by Enakirerhi and Temile support that IPPIS is on implementation stage in their study which explores the Integrated Personnel and Payroll Information System (IPPIS) in Nigeria by looking critically at the challenges of implementation of IPPIS, benefits to be derived when IPPIS is fully implemented and what the future holds.

There were series of workshops for stakeholders to discuss the benefits of the IPPIS policy by the then Minister of Finance, Mr. Olusegun Aganga before the eventual flag off of Integrated Personnel and Payroll Information System. One of such workshops was the IPPIS Phase II workshop held at the Sheraton Hotels Abuja. If implementation involves the committal of funds, the establishment of structures and methods, the hiring of personnel, the administering or executing of activities, and the securing of policy goods, services and other intended outcomes as claimed by Ikelegbe (1996). Huge money was assigned for the policy take off according to the Bureau of Public Service Reforms (BPSR) when El Rufai was chairman, a sum of $\$ 4.9$ million sponsored by World Bank contract was signed with the Nigerian Based System Specs Consortium in October 2006, for the provision of a more coherent Integrated Personnel and Payroll Information 
System (IPPIS). An Office domiciled in the Office of Accountant General of the Federation has been created for IPPIS with sizeable number of employees to oversee the smooth implementation of the policy.

\section{Empirical Literature}

Scholars have extensively written about Integrate Payroll and Personnel Information System (IPPIS) within its short time of implementation in Nigeria. For instance, Farajimakin \& Anichebe (2017) Study Effect of Integrated Personal Payroll Information System on Employee Welfare: Evidence from Federal Ministries in Nigeria the study was based on survey and descriptive research design and the data were collected using questionnaire structured in hinaty format. Binary logistic regression analysis was employed. The result of the study showed that, the implementation of IPPIS had weak positive relationship with employee welfare but it is statistically significantly.

In another study by Farajimakin \& Anichebe (2017) on Integrated Payroll System and Government Recurrent Expenditure in Nigeria. The study used both qualitative and quantitative method of research. Data were collected through primary and secondary sources. The secondary was collected from annual reports of Bayelsa State Government, Nigeria and survey data were obtained from 30 respondents using researcher-designed questionnaire validated by experts and shown to have a reliability coefficient of 0.90 . Descriptive and ordinary least square regression statistical techniques were used in analyzing the data with the aid of Statistical package for Social Sciences (SPSS) version 21. The study found that, there was positive and strong relationship between integrated payroll system and personnel cost and overhead cost.

In the study of Leyira \& Temple (2018) on IPPIS and the Ghost Workers Syndrome in Nigeria's Public Sector. The study adopted a historical research method and its finding was that the implementation and deployment of Integrated Personnel and Payroll Management System (IPPIS) have to a great extent reduced the incentive, capacity and opportunity of fraudulent individuals to perpetrate payroll fraud at all levels.

While the study by Agboola (2018) on Effectiveness of Integrated Personnel and Payroll Information System in Addressing Ghost Worker Syndrome in Nigerian Public Sector was a survey research. The study utilized primary and secondary sources of data to elicit the opinions of public servants in the Federal Inland Revenue Service (FIRS). The study revealed that there were still challenges facing IPPIS in uploading monthly salary of the employees. The study concluded that with the introduction of the IPPIS scheme, if properly implemented and managed, it will go a long way in eradicating ghost workers in the Nigeria public service.

The study by Mela (2019) on The Implementation of IPPIS Policy in The Nigerian Universities by Federal Government: Benefits and Challenges. The study was a qualitative research typed. The study revealed that, university system did 
not reject IPPIS but argued that IPPIS did not adequately capture university flexibility and peculiarities.

In their own study, Kaoje, et al., (2020) which focused on Integrated Personnel and Payroll Information System (IPPIS) and Transparency in Government Payroll Administration in Nigerian Civil Service: A Unique Approach. The study was carried out with descriptive cross-sectional survey research design. The study found a significant moderate positive relationship between IPPIS, Transparency and Accountability.

Enakirerhi \& Temile (2017) study on IPPIS in Nigeria: Challenges, Benefits and Prospects. The study was a theoretical one that relied on various federal government announcement, opinions, stakeholders, presentations to international bodies and various articles and newspaper publications to reach its conclusion. The study found that accurate and reliable personnel, reduction or elimination of corrupt and sharp practices, facilitation of modern scientific and accurate budgeting and forecasting were major benefits of IPPIS. These benefits according to the study were however threatened by skills transfer problem, poor supporting infrastructure, technological barriers for inter MDAs transfer, resistance from stakeholders and lack of will for accelerated implementation.

Idris, Adaja \& Audu (2015) study on Integrated Personnel Payroll and Information System (IPPIS) Panacea for Ghost Workers Syndrome in Nigerian Public Service. The study elicited data from both primary and secondary sources. The data were analyzed using the simple percentage, frequency tables, mean score and spearman rank order correlation technique. The study found that ghost workers syndrome was rampant in the public service and that the integrated personnel payroll and information system (IPPIS) if properly adopted in the public service, it would ensure a virile economy through enhance productivity.

Effiong et al., (2017) study which examined the Effects of Treasury Single Account (TSA), Integrated Payroll and Personnel Information System (IPPIS), and Integrated Financial Management Information System (IFMIS): Application and Implementation Effects on Fraud Management in the Public Sector in Nigeria. The study was conducted using descriptive research design with questionnaire administered on respondents randomly selected from the studied Ministries. The linear regression model was employed in establishing the relationship between variables and the study finding showed that TSA, IPPIS, and IFMIS have positive and significant relationship with Fraud and fraud management as well as jointly impact the performances of Public Interest Entities.

\section{Literature Gap}

Knowledge is lacking regarding the impact of IPPIS policy implementation on public service salary administration in Nigeria. Previous studies focused on how the implementation of Integrated Personnel Payroll and Information System has 
been deployed to detect ghost workers, payroll fraud and to save money to government treasury. Works by Idris, Adaja \& Audu (2015), Agboola (2018), Leyira \& Temple (2018), and Effiong (2017) supported this conclusion. Work by Enakirerhi \& Temile (2017), established the effectiveness as well as challenges of IPPIS implementation in Nigeria while works by Effiong focused on relationship between IPPIS and TSA and IFMIS. The study of Kaoje, et al., (2020) established relationship between IPPIS and Farajimakin \& Anichebe (2017) established relationship between IPPIS, personnel cost and overhead cost and also demonstrated weak relationship between IPPIS and employee welfare. None of the Scholars in recent studies, to the best of my knowledge measures the impact of IPPIS policy implementation to $\mathrm{x}$-ray the gains and pains on public service in Nigeria a gap which this study intends to fill.

\section{Theoretical Framework}

The study adopts Decision Making Theory as its theoretical framework.

\section{Decision Making Theory}

An analysis bringing the decision-making process into the focus of political analysis was developed by Richard Snyder and his colleagues after the Second World War II. Snyder made a distinction between the static analysis so far adopted in the study of politics by the structural functionalists and the systems theorist and claimed that the decision-making analysis based as it was on process analysis, was capable of dealing with dynamic situations. A static analysis could yield information on the nature of change between two points in time and on the conditions under which the change took place but not on reason for change or how the change was actually unfolded (Varma, 2001).

In the field of decision making, Herbert Alexander Simon's Administrative Behaviour made a pioneering contribution. According to Simon (1957), decision-making is the most significant activity of administration. He argued that decision-making should be studied carefully since the deciding comes before the doing. Simon criticized the traditionalists (scholars in the classical school of thought and said that their principle is proverbs. He also criticized the idea of laying emphasis on formal organization structure of authority and allocation of functions. He prescribed an empirical approach in administration to replace the so called arm-chair speculation.

The models of decision-making attempt to simplify the real-world situation of decision making through relating how individuals and groups take decisions, what guides or informs such decision making, what information the decision maker looks for and what influence his decision (Ikelegbe, 1996). Basically, the decision-making theory can be categorized as the rational (comprehensive), satisfactory, incremental and mixed scanning model. Among the types of decision-making theories, the study finds mixed-scanning model most suitable in explaining the introduction of IPPIS. 


\section{Mixed-Scanning Model}

The Mixed-Scanning incorporated the ideas of both the ration and incremental model in public policy making and analysis. Etzioni, (1967) was the person who advanced mixed scanning model to the policy making. He considered the model to be superior to both the rational comprehensive and incremental models. In fact, like the incrementalist, he rejected rationalistic models because they were unrealistic practically and undesirable normatively. He did not also see incrementalism as an alternative to rationalism. He argued that normatively, the incremental approach which presumes that public choices arise out of the interplay of partisanship is deficient to the extent that not all community interests are represented in the process of decision.

Basically, mixed-scanning seeks to avoid the problem of rationalistic and incremental model: Its purpose is to permit the simultaneous utilization of the rational comprehensive and incremental models in different situations. While in some cases incrementalism will be adequate, in others, the rational comprehensive will be needed. Therefore, descriptively, mixed scanning can incorporate when they occur, both incremental and fundamental policy decision. Mixed scanning recognizes the limited human capacity to secure purely rational decisions (Olaniyi, 2001).

In the exploration of mixed-scanning, it is essential to differentiate fundamental decisions from incremental ones. Fundamental decisions are made by exploring the main alternatives the actor sees in view of his conception of his goals, but unlike what rationalism would indicate details and specification are omitted so that an overview is feasible. Incremental decisions are made but within the contexts set by fundamental decisions (and fundamental reviews) (Aregbesola, 2019).

Thus, each of the two elements in mixed-scanning helps to reduce the effects of the particular shortcomings of the other; incrementalism reduces the unrealistic aspects of rationalism by limiting the details required in fundamental decisions, and contextualizing rationalism helps to overcome the conservative slant of incrementalism by exploring longer-run alternatives. Together, empirical tests and comparative study of decision-makers would show that these elements make for a third approach which is at once more realistic and more effective than its components. The application of the Mixed Scanning model of decision making as a formwork of analysis became necessary since it combines incorporates the assumptions of both the rational and incremental models before coming up with a result-oriented approach to decision making.

The Integrated Payroll and Personnel Information System (IPPIS) was a process of detailed rationalistic examination of all Ministry, Department and Agency of government. The examination revealed a sharp practice in the payroll system of the MDAs. Hence, the need for mechanism to checkmate payroll fraud and ghost worker's syndrome became necessary in 2006 when it was introduced. Political actors both from the state and federal engaged in critical 
thinking and arrived at a centrally controlled and digitalized payroll system that made fraud impossible and payment of salary of public servants seamless. Apart from reducing payroll fraud, the IPPIS has been immensely beneficial to the federal government because it has helped the government to save billions of Naira which hitherto was embezzled by few corrupt elements in the public service.

According to mixed scanning model that emphasis is place on specific and details to arrive at informed decision making with affordable cost-effective time saving decision. IPPIS was piloted in 2007 with seven federal ministries which can be described as specific ministries, the review of these ministries over time showed significant level of successful implementation of IPPIS which resulted in an encompassing decision to extend it to all federal government MDAs.

The study situates IPPIS policy from the perspective of decision making taken by political actors out of series of bargaining and tradeoffs. The compelling evidences of payroll malpractices from Olusegun Aganga (former Minister of Power), El Rufai (former Minister of FCT) and Ngozi Okonjo Eweala (former Minister of Finance) were enough to convince the federal government to launch a payroll system that will eliminate ghost workers and payroll fraud as well mitigate the problems associated with salary and arrears payment of public servants in federal government service.

In other words, IPPIS was a product of mixed scanning decision making process which is based on specific to general upward review of performance over time to outright adoption by all government MDAs. The model to some extent was suitable in explaining IPPIS policy as a byproduct of compromise and lobby to savage the public service salary administration but it failed to take into cognizance the effects of such decision on implementers and the whole political environment to foster effective implementation of the payroll policy. Lastly, it erroneously failed to link decision making with organizational reform that can propel development.

\section{Data and Methods}

Secondary source of data are data that have been processed and documented by earlier scholars. They are second hand information available for consumption. In other words, the source of data for the study was secondary and they were assessed through journal, textbooks, internet and government publications form Head of Service of the federation, publications from Office of Accountant General of the Federation (OAGF) as well as IPPIS office in Abuja. Data collected were contextually and descriptively analyzed to draw informed conclusions about IPPIS.

\section{The Objectives of IPPIS}

The objectives of the programme amongst others are: 
1) To facilitate human resource planning and by providing information for decision making;

2) To provide a platform for accurate budgeting of annual recurrent expenditure on staff emoluments;

3) To monitor monthly payment of staff emoluments against FGN's annual Budget to ensure minimal wastage and leakage;

4) To facilitate easy storage, updating and retrieval of personnel record for administrative and pension processing;

5) To ensure database integrity such that, data once entered cannot be manipulated by unauthorized users;

6) To eliminate payroll fraud such as multiple payment of emoluments to a single employee or payment of monthly salary to a non-existent employee;

7) To ascertain actual personnel emoluments of the Federal Government employee; etc. (Office of Accountant General of the Federation, 2020).

Table 1 shows the enrolment status of public servants as of July 2020. In all, 701 MDAs have been enrolled with 1,121,031 public servants on the IPPIS platform.

Table 2 shows 9 Departments and Agencies of government that are not yet on the IPPIS platform. Out of this nine, three of them are petroleum related agencies and institute while two are security related agencies. About 1.2 million Public Servants are expected to be captured on IPPIS but with exclusion of Security Agencies, Para Military Organizations as well as others self-funding Agencies/Companies of the Federal Government.

Table 1. Public servants enrolment status on IPPIS as at July 2020.

\begin{tabular}{cccc}
\hline S/N & Items & MDAs & Staff Count \\
\hline 1 & MDAs & 558 & 389,758 \\
2 & Rtd. Heads of Service and Permanent Secretaries & 1 & 266 \\
3 & Nigeria Police & 43 & 292,653 \\
4 & Nigeria Army & 1 & 120,368 \\
5 & Nigeria Navy & 1 & 23,685 \\
6 & Nigeria Air Force & 1 & 21,653 \\
8 & Nigeria Immigration Service & 1 & 24,434 \\
9 & Nigeria Correctional Service & 1 & 30,478 \\
10 & NSCDC & 1 & 55,396 \\
11 & Universities, & 435 & 106,280 \\
12 & Universities Research Institutions & 1 & 4065 \\
13 & National Open University of Nigeria & 23 & 28,894 \\
14 & Federal Polytechnics & 21 & 23,100 \\
15 & Federal Colleges of Education & 701 & $1,121,031$ \\
\hline
\end{tabular}

Source: Office of Accountant General of the Federation OAGF, 2020. 
Table 2. MDAs not on IPPIS as at July, 2020.

\begin{tabular}{cc}
\hline S/N & MDAs \\
\hline 1 & Department of Petroleum Resources (DPR) \\
2 & Petroleum Product Pricing Regulatory Agency (PPPRA) \\
3 & Nigeria Nuclear Regulatory Authority, Abuja \\
4 & Accident Investigation Bureau Abuja (AIB) \\
5 & Petroleum Training Institute, Efurun, Delta State \\
6 & National Intelligence Agency (NIA) \\
7 & Office of the National Security Adviser (ONSA) \\
8 & Department of State Services (DSS) \\
9 & West African Examination Council (WAEC). \\
Total & 9 MDAs \\
\hline
\end{tabular}

Source: Office of Accountant General of the Federation OAGF, 2020.

\section{Reasons for ASUU and Other MDAs Resistance}

Academic Staff Union of University and other MDAs have shown displeasure over the plan to migrate them on IPPIS. According to the ASUU, enforcing IPPIS is an infringement on universities' right to autonomy. During a discussion with the Senate on the rejection, ASUU President, Professor Biodun Ogunyemi in ASUU Bulletin September (2019) mentioned that the enforcement is not permitted under the law. "The introduction of IPPIS is not backed by law. The Union's position is that there are extant legal provisions and negotiated agreements arising from the nature and peculiarities of Nigerian universities, which make IPPIS unnecessary and inapplicable to the universities".

As an entity, a Nigerian university is backed by an Act giving it the freedom to run itself and the introduction of a central payroll system is an infringement on this right. The IPPIS software is not robust enough to cater for the peculiarities of lecturers (ASUU Bulletin September, 2019). Outside universities, the Petroleum and Natural Gas Senior Staff Association of Nigeria (PENGASSAN) embarked on an industrial action earlier in November, 2020 over disagreements with the federal government on IPPIS. In the series of resolutions ASUU published to its members and the press in November 2019, ASUU highlighted reasons why its Union refused to enroll on IPPIS to include:

1) IPPIS violates university autonomy as enshrined in section $2 \mathrm{AA}$ of the University (Miscellaneous) provisions Amendment Act 2003 which states that the powers of Council shall be exercised as in the law and statures of each University and to that extent establishment circulars that are inconsistent with the laws and statures of the university shall not apply to the universities;

2) The peculiar nature of the appointment of the university academics;

3) It will also violate the 2009 Agreement which was negotiated, agreed and signed by ASUU and FGN; 
4) The IPPIS template is designed to phase out staff who are above (60) years, which contradicts the new policy of Professors retiring at (70) years;

5) IPPIS does not recognize payment of promotion arrears, rent allowances as it is now consolidated in our salary;

6) IPPIS does not capture the technicalities and peculiarities associated with the flexibility and mobility of academics in the university system;

7) The IPPIS template adopts a tax payment system known as ptax 2 which is inimical to our members on consolidated salary (ASUU, 27 th $^{\text {November }} 2019$ Resolutions).

Apart from ASUU, NNPC subsidiaries too opposed plan to enroll on IPPIS. The affected agencies include the Department of Petroleum Resources (DPR), Petroleum Products Pricing Regulatory Agency (PPPRA), Petroleum Equalization Fund (PEF), Petroleum Trust Development Fund (PTDF), the Nigerian Content Development Monitoring Board (NCDMB), Nigerian Nuclear Regulatory Agency (NNRA) and Petroleum Training Institute (PTI). They accused the OAGF of insisting on enrolling their members on the IPPIS platform without taking into consideration the peculiarities of the oil and gas industry with regards to the Collective Bargaining Agreement (CBA) and approved pay structure between the unions and the federal government through the Salaries, Wages and Income Commission. Besides, they said the OAGF's insistence on the enrolment of the affected agencies on IPPIS did not consider that they were already enrolled on the revived Government Integrated Financial Management Information System (GIFMIS).

\section{Assessing Achievements of IPPIS in Nigeria}

In evaluating the study assumption (1) that the implementation of IPPIS policy in Nigeria has resulted into lots of achievement and gains to the public servants and the nation at large, the achievement of IPPIS policy in Nigeria as well as the gains which the implementation of the policy has brought about as used to validate the assumption.

The quality of government payroll administration has vastly improved and an increasing number of MDAs are moving away from manual payroll administration. The MDAs have the necessary information for planning their personnel costs. IPPIS has actually reduced corruption by virtually eliminating ghost-worker syndrome where applied, thereby reducing the cost of governance. The

Scheme has, from its launch in 2007 to December 2014, saved the government N185 billion (about US\$1 billion), representing the difference between the money that government would have released to MDAs based on their estimated nominal roll submissions and the amount actually paid through the IPPIS platform.

A breakdown of this shows that $\$ 416$ million was saved in its first month of operation and 12 billion at the end of its three-year pilot phase. The scheme 
now covers 359 MDAs and has successfully enrolled 237,917 members of staff and weeded out 60,450 ghost workers. Furthermore, it reduced the red tape involved in manual payroll administration (Office of Accountant General of the Federation, OAGF, 2020). Within 13 years of IPPIS implementation, the payroll policy has recorded some remarkable achievements.

\section{Achievements of IPPIS Are:}

1) Improved prompt and regular payment of salaries of MDAs;

2) Facilitation of prompt deductions and remittances to the accounts of all third-party stakeholders e.g., PFAs, NHIS etc.

3) Over N361 Billion savings in personnel cost recorded between 2017 and 2019;

4) Financial/personnel variances trend is easily accessible and available;

5) It makes personnel planning/budgeting easy since IPPIS is also a personnel management tool;

6) Enforcement of compliance with due process on employment;

7) IPPIS big data in various organizations are being transformed into a rich source of information which could be leveraged to make rich decision about government operations;

8) Many of the Departments and Agencies having realized that personnel cost was no longer coming to them for direct disbursement, embarked on recruitment to utilize their approved manpower/personnel budget; Between September, 2011 and 2020, so many Nigerians have been employed in the MDAs thereby reducing unemployment rate in the country; and

8) MDAs are getting used to the application and many are currently managing their payroll at their respective offices without recourse to IPPIS Secretariat (Office of Accountant General of the Federation, OAGF, 2020).

\section{Gains of IPPIS to the Country}

1) Elimination of unauthorized personnel workforce (ghost workers) from Government payroll;

2) Easy retrieval of personnel information of all public servants under the scheme;

3) Reduction in personnel records' falsification record of service (including age, length of service; etc.;

4) Salary/monthly emoluments are paid to all public servants on the scheme same day no matter the location within the country without delay;

5) Actual personnel cost paid monthly/annually are easily accessible with reason(s) for fluctuation easily given;

6) The scheme programmed automatic stoppage of payment to personnel due for retirement as a result of length of service, age and tenure thus reducing wastage or unauthorized payment;

7) All third parties' payment (cooperative deduction, tax, NHF and Union 
dues, etc.) are affected from employee's salary and paid directly and promptly to beneficiaries account on behalf of payee with schedule of payment made available to the beneficiaries;

8) Unapplied/unutilized fund are easily monitored;

9) Planning/budgeting for training of personnel can now be done easily since IPPIS is also a personnel management tool;

10) Saving to government as a result of personnel cost over-budgeting (Office of Accountant General of the Federation, OAGF, 2020).

From the above achievement and gains, it crystal clear that IPPIS implementation has resulted in massive saving into federal covers, prompt and accurate salary payment, generate data or personnel and overhead budgeting, halted ghost workers etc. it is logical to infer that the implementation of IPPIS policy in Nigeria has resulted into lots of achievement and gains to the public servants and the nation at large.

\section{Challenges and Pains of IPPIS}

To evaluate the second assumptions that: the implementation of IPPIS policy in Nigeria has created challenges which affect public servants and government adversely, the challenges as well as the Pains associated with the implementation of IPPIS as highlighted below helps in validating the assumption.

1) Deliberate Institutional resistance by many MDAs in joining IPPIS in the face of set deadline for enrolment. Stiff resistance from the unions in the Tertiary Institutions more especially ASUU in the Universities and resort to incessant blackmail of IPPIS on the media for selfseeking objectives.

2) Inadequate Infrastructure: Poor internet connectivity to the Primary Data Centre (PDC) by MDAs on IPPIS and inadequate computer hardware for IPPIS Role Players. This inhibits efficiency and effectiveness in service delivery.

3) The IPPIS application has not been fully utilized. Of the seven modules on the software, only the payroll module is in appreciable use. The Human Resource modules, which are meant to manage staff recruitment, posting, promotion, training, discipline, and disengagement, are yet to be fully deployed for use by MDAs Service-Wide. The current vendor has not delivered everything contracted and paid for and the project management of the initiative has been weak.

4) Most of the IPPIS Staff in the MDAs have not been exposed to Oracle Training and some of the few that received the training have been deployed to other MDAs (Office of Accountant General of the Federation, OAGF, 2020).

5) Lack of Synergy between MDAs Desk Officers and OAGF: Finding revealed that lack of effective synergy between the two major partners was a major setback for IPPIS implementation. The WhatsApp platform created for IPPIS Desk Officer by Office of the Accountant General of the Federation for the purpose of interacting about the challenges bedeviling the IPPIS implementation has not be active. It is ridiculous that members of the platform have never for once met to discuss about these challenges and there was no official meeting to interface with 
the officials of Office of the Accountant General of the Federation.

6) Delayed Response to complain and over-centralization: Public servant who is victims of under/over payment or complete omission of salary experienced a lot of difficulty in getting their cases addressed. Some who are working outside Abuja after series of unattended complaints from their MDAs Desk Officers resulted into travelling to OAGF in Abuja with more financial burden to shoulder. Often times, they were reversed to their MDAs Desk Officers from Abuja without solution while others get the problem fixed in Abuja. But the stress and timeline of getting the complaint addressed put such victims in more precarious condition because lots of unmet needs which might demotivate workers.

7) Lack of Technological Transfer: Most often, there are two-way technical hitches experience by the officials of the OAGF who claimed the consultants did not show them the complete technical know how to handle the platform properly while the MDAs Desk Officers on their own part alleged the OAGF of not giving them enough access to the platform as well as technical knowhow. The exact location of IPPIS server is shrouded in secrecy.

8) Sharp Practices by IPPIS Handlers: The IPPIS project has also had some scandals coming from it. Police inspectors and rank and file under the Akwa Ibom State Police Command and some personnel of the Nigeria Security and Civil Defense Corps have called on the authorities to investigate inconsistency in the payment of their salaries. They queried the operation of the IPPIS, saying they suspect fraud. The police officers involved have been suffering underpayment of their regular salary every month since 2018 when payment of police salaries and allowances was moved from Mechanized Salary Section (MSS) to the IPPIS (Nduka, 2019). In his own testimony, the former Chairman of Independent Corrupt Practices and other Related Offences

Commission (ICPC), Ekpo Nta alleged that "by outsmarting the Federal Government Integrated Personnel Payroll Information System (IPPIS), some public servant allegedly collected salaries from four different federal ministries. Some unidentified software developers have unhindered access to the database of IPPIS and usually set up new users and change live data, from time to time".

9) IPPIS and Corruption: Issuing of payment slip without salary payment is another corrupt practice in IPPIS office. Once the payment slip is being issued out the money is gone and nothing can be done. Even after writing complaints letter Months after the letter was written, the affected workers were unable to get any response. It was also alleged that there are cabals in the finance section of the IPPIS that embezzle monies meant for workers in the federal civil service but issue pay slips to show salaries are paid (Sahara Reporters July 27, 2019).

It is evident with these aforementioned challenges that IPPIS has created some other challenges while trying to solve others. In other word, we can infer that IPPIS implementation has resulted in creating some challenges that adversely affected public servants and government. 


\section{Limitations of the Study}

The study was limited by lack of enough data that would have enriched the paper. This limitation was associated with the bureaucratic bottleneck associated be accessing reliable data in Nigerian public service. Another limitation was the repeated visits to IPPIS office and some MDAs. Most often, appointments were canceled without cogent reasons while in some cases, government officials who are in charge of research/archival materials shift responsibility to frustrate researchers. But with perseverance and persistency, the challenges were surmounted. The challenges notwithstanding did not in anyway invalidate the findings/conclusion of the study.

\section{Conclusion}

Since its full implementation in Nigeria, IPPIS has recorded lots of achievements in the area of public service salary payment, identified ghost workers and checkmated payroll fraud as billions of naira has been saved to federal government covers through this modern innovation. Despite these lofty gains, the IPPIS policy implementation was associated with some challenges that affected the smooth implementation of the policy in Nigeria. Such includes: under/over payment or complete omission of public servants' salary and entitlement, lack of technological transfer, lack of synergy between and among stakeholders, sharp practice, resistance of MDAs to enroll and corruption. These challenges impact on the wellbeing of public servants and that of the nation.

\section{Recommendations}

Based on this striking conclusion, the authors strongly believed that, if these challenges identified by the Study can be speedily addressed, the IPPIS will be a major reform that is capable of reinvigorating the public service payroll system in Nigeria. Therefore, the study recommends that:

1) Since IPPIS has generated lots of funds to the government, federal government should separate IPPIS office from the Office of Account General of The Federation to allow for more autonomy in order to function optimally and allow more decentralization.

2) That all loop holes must be blocked to discontinue all forms of sharp practices and corruption currently embedded in the payment platform. This can be achieved by periodic review of the platform to identify leakages and subsequently block such economic sabotage.

3) There is need to foster more synergy between and among stakeholders for collaborative efforts to enhance speedy problem-solving skills. This can be achieved by assigning specific roles to specific office with a more harmonized coordination that will allow for decentralization or delegation of roles, i.e., public servants must not always travel to Abuja before they get their complains attended to.

4) That the IPPIS consultants/engineers should redesign or remodify the 
software to accommodate more organizational flexibility and peculiarity. By doing this, those federal workers who have hitherto resisted the payment platform can be convinced that the software can be modified to suit their differences.

\section{Conflicts of Interest}

The authors declare no conflicts of interest regarding the publication of this paper.

\section{References}

Agboola, T. O. (2018). Effectiveness of Integrated Personnel and Payroll Information System in Addressing Ghost Worker Syndrome in Nigerian Public Sector. https://www.semanticscholar.org/paper/Effectiveness-of-IntegratedPersonnelandPayro llOlumuyiwa/a7ef088ba84e7b837893126a9b4f578411e96178

Amdii, I. E. S. (2010). Public Policy Analysis Lecture Notes. University of Abuja.

Anderson, J. (1984). Public Policy Making. Holt Reinhart and Winston.

Aregbesola, M. A. (2019). Impact of Urban Transportation Policy on the Development of Federal Capital Territory (FCT). Ph.D. Thesis, Department of Political Science, Nasarawa State University.

Cochran, C. L. (2015). Public Policy: Perspectives and Choices (3rd Edition). McGraw-Hill.

Dlakwa, H. (2008). Concepts and Models in Public Policy Formulation and Analysis. PylaMark Services Ltd.

Dye, T. R. (1995). Understanding Public Policy(8th ed.). Prentice Hall.

Effiong, S. A., Oro, B. L., Ogar, G. U., Imong, N. R., Jacob, G. E., \& Iroushu, R. B. (2017). Treasury Single Account (TSA), Integrated Payroll and Personnel Information System (IPPIS), and Integrated Financial Management Information System (IFMIS): Application and Implementation Effects on Fraud Management in the Public Sector in Nigeria. IOSR Journal of Business and Management, 19, 22-30.

https://www.researchgate.net/publication/331839443 Treasury Single Account Tsa I nte-

grated Payroll and Personnel Information System Ippis and Integrated Financial Manage-

ment Information System Ifmis Application and Implementation Effects on Frau d Manag

Enakirerhi, L. I., \& Temile, S. O. (2017). IPPIS in Nigeria: Challenges, Benefits and Prospects. International Journal of Social Science and Economic Research, 2, 3490-3497. http://www.abrj.org/publications-of-abrj/article/129/

Etzioni, A. (1967). Mixed-Scanning: A “Third” Approach to Decision-Making. Public Administration Review, 27, 385-392. https://doi.org/10.2307/973394 https://www.researchgate.net/publication/235356796 Mixedscanning A Third Appro ach to Decision-making

Farajimakin, A. S., \& Anichebe, A. S. (2017). Effect of Integrated Personal Payroll Information System on Employee Welfare: Evidence from Federal Ministries in Nigeria. Australian Journal of Arts and Scientific Research, 22, 1-143.

https://www.scribd.com/document/456473058/Effectofintegratedpersonalpayrollinfor mationsystemonemployeewelfareanichebea-s

Freeman, B. (2013). Revisiting the Policy Cycle, Association of Tertiary Education Man- 
agement (ATEM), Developing Policy in Tertiary Institutions. Northern Metropolitan Institute of TAFE (NMIT).

Howlett, M., \& Ramesh, M. (2003). Studying Public Policy: Policy Cycles and Policy Subsystems. Oxford University Press.

Idris, A. Adaja, J., \& Audu, J. S. (2015). Integrated Personnel Payroll and Information System (IPPIS) Panacea for Ghost Workers Syndrome in Nigerian Public Service. International Journal of Public Administration and Management Research (IJPAMR), 2, 55-64.

https://citeseerx.ist.psu.edu/viewdoc/download?doi=10.1.1.1058.1118\&rep=rep1\&type $=\mathrm{pdf}$

Ikelegbe, A. O. (1996). Public Policy Making and Analysis. Uri Publishing Limited.

Ikelegbe, A. O. (2006). Public Policy Analysis: Concepts, Issues and Cases. Imprint Services. Institute of Nigeria. Integrated Personnel and Payroll System Operational Manual.

Kaoje, A. N., Nabila, K., Idris, S., Gambarawa, J. A., \& Ubandawaki, L. I. (2020). Integrated Personnel and Payroll Information System (IPPIS) and Transparency in Government Payroll Administration in Nigerian Civil Service: A Unique Approach. Asian Journal of Economics, Business and Accounting, 19, 1-8.

https://citeseerx.ist.psu.edu/viewdoc/download?doi=10.1.1.1058.1118\&rep=rep1\&type $=\mathrm{pdf}$

https://doi.org/10.9734/ajeba/2020/v19i330303

Leyira, C. M., \& Temple, M. (2018). IPPIS and the Ghost Workers' Syndrome in Nigeria's Public Sector. Scholars Journal of Economics, Business and Management (SJEBM), 5, 773-778.

http://saspjournals.com/wp-content/uploads/2018/09/SJEBM-58-773-778-c.pdf

Mela, K. (2019). The Implementation of IPPIS Policy in the Nigerian Universities: Benefits and Challenges. Global Journal of Applied, Management and Social Sciences (GOJAMSS), 17.

http://www.gojamss.net/journal/index.php/gojamss/article/view/504

Nduka, C. (November 2019). Understanding Integrated Personnel and Payroll Information System. The Nation.

https://thenationonlineng.net/understanding-integrated-personnel-and-payroll-inform ation-system/

Office of the Accountant General of the Federation, IPPIS Department Publication, (2012)

Office of the Accountant General of the Federation, OAGF (2020)

Ogunyemi, B. (2019). ASUU Resolutions of UniAbuja Emergency Congress Held on Wednesday 27th November, 2019 at Political Science Parliamentary Building, Mini Campus, University of Abuja.

Olaniyi, J. O. (2001). Foundation of Public Policy Analysis. Sunad Publishers Ltd.

Public Service Institute of Nigeria Bulletin Publication (2011) Series 7

Sahara Reporters (2019) How Office of Nigeria's Accountant General Refused to Pay Civil Servants Five Months' Salaries?

http://saharareporters.com/2019/07/27/exclusive-corruption-how-office-nigeria\%E2\%

$\underline{80 \% 99 \mathrm{~s}-\text { accountant-general-refused-pay-civil-servants }}$

Simon, H. (1957). Administrative Behaviour. The Macmillan Co.

Varma, S. P. (2001). Modern Political Theory. Vikas Publishing House, PVT Ltd. 